\title{
Life-cycle assessment of a house with alternative exterior walls: Comparison of three impact assessment methods
}

\author{
Helena Monteiro, Fausto Freire* \\ ADAI-LAETA, Department of Mechanical Engineering, University of Coimbra, Pólo II Campus, Rua Luís Reis Santos, 3030-788 Coimbra, Portugal
}

\section{A R T I C L E I N F O}

\section{Article history:}

Received 7 February 2011

Received in revised form 8 December 2011

Accepted 22 December 2011

\section{Keywords:}

Building envelope

Primary energy

Environmental impacts

Life-cycle assessment

Single-family house

Cumulative energy demand

Eco-indicator'99

CML 2001

\begin{abstract}
A B S T R A C T
A life-cycle (LC) model has been implemented for a Portuguese single-family house. The first goal is to characterize the main LC processes (material production and transport, heating, cooling, maintenance) assessing seven alternative exterior walls for the same house to identify environmentally preferable solutions. The second goal is to compare the results of three life-cycle impact assessment (LCIA) methods CED (cumulative energy demand), for primary energy accounting; CML 2001 (Institute of Environmental Sciences of Leiden University) and EI'99 (Eco-indicator'99), for multiple environmental impacts - to determine the extent to which the results of a life-cycle assessment are influenced by the method applied. The results show that the most significant LC process depends on the operational pattern assumed. Regarding the assessment of the exterior wall alternatives, the results indicate the wood-wall is the preferable solution. Non-renewable CED shows results similar to abiotic depletion (CML 2001) and resources (EI'99) categories, as well as some correlation with climate change/global warming potential (GWP), acidification and eutrophication. However, no correlation was found with the remaining impact categories. Comparing CML 2001 and El'99 categories, GWP, ozone layer depletion, abiotic depletion, acidification, and eutrophication present robust results that permit a straightforward comparison between the two LCIA methods. Nevertheless, CML results present slightly higher impacts for the use phase, while EI'99 for material production. In addition, the two LCIA methods can present inconsistent results between similar categories (different ranking of alternatives), which ultimately can influence the choice among solutions.
\end{abstract}

(c) 2011 Elsevier B.V. All rights reserved.

\section{Introduction}

In the European Union (EU), the housing sector accounts for a substantial amount of energy consumption and environmental impacts [1]. To address this sector, EU regulations have been developed [1-3] focusing on reducing the operational energy consumption of dwellings, but disregarding the full lifecycle environmental impacts. A comprehensive assessment of the energy use and environmental impacts of buildings requires a life-cycle perspective to quantify the various impacts and to identify improvement opportunities towards more sustainable solutions. Life-cycle assessment (LCA) methodology, which has gained increased international acceptance, addresses the potential environmental impacts throughout a product life-cycle (LC). LCA can be applied to decision-making in order to improve the environmental performance of buildings.

LCA studies performed for dwellings have mainly focused on energy requirements and greenhouse gas (GHG) emissions. A small number of recent LCA have studied multiple environmental

\footnotetext{
* Corresponding author. Tel.: +351 23979039; fax: +35135123979001.

E-mail address: fausto.freire@dem.uc.pt (F. Freire).
}

impacts, often using differing life-cycle impact assessment (LCIA) methods with non-comparable or contradictory conclusions [4-10]. For building LCA practitioners it is not obvious which LCIA method to choose and neither whether the interpretation of results from different methods leads to coincident or contradictory conclusions [11]. Since impact categories, characterization indicators and characterization factors vary between LCIA methods, a meaningful comparison between methods is difficult to perform. Furthermore, none of the published studies has used multiple LCIA methods to assess dwellings to determine whether the LCA findings are influenced by the LCIA method applied.

This article presents an LCA for a Portuguese single-family house comparing seven alternative exterior wall solutions aimed at identifying environmentally preferable solutions. In this research, the main life-cycle processes affected by the building envelope (material production and transport, heating, cooling, maintenance) have been characterized in terms of energy and environmental impacts, considering two alternative operational patterns. Not included is the energy requirement of other operation-phase activities (electric appliances, lighting, cooking, domestic hot water) since it is not affected by the exterior wall solution. In this research, three LCIA methods have been used: CED (cumulative energy demand), for life-cycle primary energy accounting; CML 2001(Institute of 
Environmental Sciences of Leiden University, 2001) and EI'99 (Ecoindicator'99), for multiple environmental impacts. These methods have been compared to determine the extent to which the results of an LCA are influenced by the method applied.

This paper has six sections, including its introduction. Section 2 presents a review of life-cycle studies of dwellings. Section 3 describes the LCA methodology and the impact assessment methods used. The life-cycle inventory and model implemented are described in Section 4. Results for the exterior-wall house scenario analysis are discussed in Section 5. The final section is the conclusion.

\section{Literature review}

The first life-cycle (LC) studies for residential buildings were published about 15 years ago, e.g. [12-15]. For example, Adalberth [13] proposed a methodology to account for LC energy of buildings from cradle to grave and applied it to three Swedish single-family houses prefabricated in a factory [12]. Among other results, Adalberth [12] concluded that the building use phase requires $85 \%$ of the total LC energy, while construction materials amount to $15 \%$. Keoleian $[14,15]$ evaluated LC energy, greenhouse gas (GHG) emissions, and costs of a single-family house in Michigan to find opportunities for conserving energy throughout pre-use, use, and demolition phases. Since then, a number of LC studies of dwellings [4-9,12,16-22] as well as a few review papers [23-26] have been published.

The majority of studies (e.g. [5,6,12,13,17-21]) have been implemented for cold climate houses and have shown that the operational phase has a preponderant weight in overall energy requirement and GHG emissions. Nonetheless, a few recent studies have pointed out that, for very-low-energy buildings, the nonoperational phase is the most significant $[4,5,27]$. Only a small number of LCA studies of dwellings have addressed a wider range of environmental impacts. Some of those studies [4-10] compared alternative building scenarios and are reviewed below. Peuportier et al. [6] performed an LCA for three different houses in France ((i) a conventional house with concrete blocks; (ii) a house with a solar heating system; and (iii) a high-insulated wood house). The CML 92 LCIA method was used, and results for twelve impact categories were presented comparing the three houses. The wood high-insulated house had generally the lowest impacts, holding about half of the concrete house impacts for nine categories.

Citherlet and Defaux [5] compared three houses: a Swiss standard house; a low-energy house that complies with the Minergie standard; a passive house (with increased insulation, a ventilation heat recovery system, solar collectors and photovoltaic panels). LCIA results were calculated based on three CML 92 categories (global warming potential (GWP), acidification, and photochemical oxidation (PO)) as well as non-renewable energy (NRE) requirements. Considering the Swiss electrical mix, the results showed that NRE was reduced by $33 \%$ in the Minergie house and $66 \%$ in the passive house in comparison to the standard house. Concerning CML 92 impacts, the two low-energy houses presented a similar performance with significant reductions (e.g. 62\% for GWP, $29 \%$ for PO, and $10 \%$ for acidification) relative to the Swiss standard house.

Blengini and Di Carlo [4] assessed a low-energy house for northern Italy and compared it with a standard house assuming a 70-year lifetime. LCIA results were presented at two levels: (i) mid-point indicators, which are representative of environmental problems and based on international conventions (primary energy (PE), NRE, GWP, acidification, eutrophication, ozone layer depletion (OLD), and PO); (ii) single score end-point indicators, which are more uncertain, but might simplify the decision process (El'99, Ecological footprint, EPS 2000). The low-energy house presented a reduction of impacts relative to the standard house; however, the magnitude of the reduction varied with the end-point indicator used (e.g. reduction of $60 \%$ for NRE, 52\% for EI'99, and 38\% for EPS2000). Furthermore, the results showed that material-related impacts were the most significant for the low-energy house, while for the standard house, heating was the most important process.

More recently, a comprehensive European study [8,9] assessed various types of EU dwellings, addressing different improvement options. They have focused on single-family houses and two kinds of apartment buildings, considering both existing and new dwellings. The LCIA results were presented for six mid-point CML impact categories (PE, GWP, acidification, eutrophication, OLD, and PO); toxicity categories were not considered because they still lack scientific robustness [8,9]. The results obtained for new dwellings showed that the building envelope had a significant part of the LC environmental impacts. The exterior walls and the roof were found to be the most important building components.

Some publications have focused on exterior walls. For instance, Ortiz et al. [7] assessed the construction phase of an apartment block considering typical Spanish exterior and interior wall scenarios. The CML method was used to assess acidification, GWP, ionizing radiation, and OLD impacts as well as energy and resource consumption. The steel elements, in particular galvanized steel, were responsible for high environmental impacts. Ortiz et al. [7] concluded that the LCA results can support the selection of the constructive combinations with the lowest impacts. Frenette et al. [10] compared five factory-built wood-frame exterior walls for a house in Quebec (Canada) concerning energy and three LCIA methods: TRACI; Impact 2002; and El'99. Midpoint results were calculated for the mentioned methods and endpoint results were presented for Impact 2002 and El'99. The goal of Frenette et al. [10] was to support the selection of an appropriate environmental index to be included in a multi-criteria decision analysis evaluation. The results showed that wood framing had a small contribution to total embodied impacts. Slightly different rankings of the exterior walls were observed for some midpoint category results obtained with the three methods, namely, respiratory organic, eutrophication, and mineral results. Nevertheless, Frenette et al. [10] concluded that endpoint results generally presented a similar ranking of alternatives, and that it seemed acceptable to use climate change category as a single environmental index.

\section{LCA methodology and LCIA methods}

Life-cycle assessment (LCA) has four interrelated phases: goal and scope definition; life-cycle inventory (LCI); life-cycle impact assessment (LCIA) and interpretation [28,29]. In the LCIA, inventory data is aggregated into specific environmental impact categories according to a method. Different LCIA methods will lead to distinct results (values, impact categories, units). LCIA methods can be single-category (e.g. primary energy, exergy, global warming potential) or multi-category, with specific sets of impact categories. Multi-category LCIA methods can be problem-oriented or damage-oriented. Problem-oriented methods (e.g. CML 2001) have midpoint impact categories and model problems at an early stage in the cause-effect chain, allowing a more transparent assessment and limiting the uncertainties. Damage-oriented methods (e.g. Ecoindicator'99) model the cause-effect chain up to the endpoints (damage to humans and ecosystems), have a narrowed set of categories, and have higher uncertainty than midpoint methods.

In this research, the variability between LCIA results has been assessed by applying to the same life-cycle inventory three methods: a general single-issue method - the cumulative energy demand (CED) - to account for life-cycle primary energy requirements, and two well-known environmental LCIA methods - CML 
Table 1

CML 2001 and Eco-indicador'99 impact categories.

\begin{tabular}{|c|c|c|c|}
\hline CML 2001 category & Unit & Eco-indicator 99 category & Unit \\
\hline Abiotic depletion (AD) & kg Sb equiv. & $\begin{array}{l}\text { Fossil fuels } \\
\text { Minerals }\end{array}$ & $\begin{array}{l}\text { MJ surplus } \\
\text { MJ surplus }\end{array}$ \\
\hline $\begin{array}{l}\text { Acidification (Acid) } \\
\text { Eutrophication (Eut) }\end{array}$ & $\begin{array}{l}\mathrm{kg} \mathrm{SO}_{2} \text { equiv. } \\
\mathrm{kg} \mathrm{PO}_{4} \text { equiv. }\end{array}$ & Acidific./eutrophi. & $\mathrm{PDF}^{*} \mathrm{~m}^{2} \mathrm{y}$ \\
\hline Global warming potential (GWP) & $\mathrm{kg} \mathrm{CO}_{2}$ equiv. & Climate change & DALY \\
\hline Ozone layer depletion (OLD) & kg CFC-11 equiv. & Ozone layer & DALY \\
\hline Photochemical oxidation (PO) & $\mathrm{kg} \mathrm{C}_{2} \mathrm{H}_{4}$ equiv. & Resp. organics & DALY \\
\hline Freshwater ecotoxicity (Fecot) & kg 1,4-DB equiv. & Ecotoxicity & $\mathrm{PDF}^{*} \mathrm{~m}^{2} \mathrm{y}$ \\
\hline \multicolumn{4}{|l|}{ Marine ecotoxicity (Mecot) } \\
\hline \multirow{4}{*}{ Human toxicity (Htox) } & kg 1,4-DB equiv. & Carcinogens & DALY \\
\hline & & Resp. inorganics & DALY \\
\hline & & Radiation & DALY \\
\hline & & Land use & $\mathrm{PDF}^{*} \mathrm{~m}^{2} \mathrm{y}$ \\
\hline
\end{tabular}

2001 and Eco-indicator'99 - to assess multiple environmental impacts. CED quantifies the total energy resource depletion and implicitly takes into account energy quality, since primary energy is the sum of final energy with all transformation losses [30]. CED (MJ equiv.) is calculated based on the higher heating value and distinguishes renewable (Renew) and non-renewable (Non-R) energy sources [31]. Non-renewable CED is very important to assess the depletion of fossil energy resources or the renewability of a system [30] and it is a widely used indicator to assess the energy LC performance of buildings. The CML 2001 and Eco-indicator'99 (EI'99) LCIA methods are broadly used in LCA studies, but have not been much used for buildings. Table 1 shows the impact categories of CML 2001 and El'99 and their respective impact indicators [31]. Related categories are placed in the same line.

Developed by the Institute of Environmental Sciences (CML) of Leiden University, CML 2001 is a problem-oriented method with ten impact categories in the baseline version (Table 1). Toxicity categories normally are not addressed because they have high uncertainty and lack scientific robustness $[8,32]$. To perform a transparent comparison between the two LCIA methods, the four toxicity categories have been included in our calculations; however, the lack of scientific robustness has been taken into account in the interpretation of results. The Eco-indicator'99 characterization is firstly made for eleven impact categories (Table 1), which, according to their impact indicator, can be grouped in three damage categories: human health; ecosystem quality; and resources [31]. The damage to human health is expressed in disability adjusted life years (DALY). The ecosystem quality damages are expressed in potentially disappeared fraction of species in a certain area over a period of time $\left(\mathrm{PDF}^{*} \mathrm{~m}^{2} \mathrm{y}\right)$. The damage to resources is expressed in surplus energy to extract minerals or fossil fuels (MJ surplus) [31]. More detailed information on the assumptions underpinning the LCIA methods (characterization factors to aggregate the LCI in the impact indicators of the impact categories) can be found in [33] for CML 2001, and in [34,35] for El'99.

The magnitude of LCIA results can be further calculated relatively to some reference information (a common scale to all impact categories, normally representing the background impact from society's total activities). This is called normalization and its aim is better understand the relative significance of each indicator result in order to facilitate the interpretation of results. In addition, normalization may be also helpful in checking for inconsistencies. The CML method has different sets of normalization: World (1990), Western Europe (1995) and the Netherlands (1997). In the present research, the Western Europe context has been adopted. The normalization calculation consists of dividing the LCIA results of each impact category per the reference value (the total impact from emissions, extractions, radiation, and land use, per impact category for Western Europe over a year) [31,33].
Concerning EI'99, normalization is performed on damage category level and it is dependent on the perspective chosen. There are three perspectives within the EI'99 method: hierarchist; individualist and egalitarian. According to [34,35], the individualist perspective values short term emissions whose impacts are scientifically proven, assuming that long term impacts are unrealistic because they will be avoid by future technology. The egalitarian perspective considers that all future generations are equally important to the present population; therefore, it values all possible effects considering a very long-term time frame. The hierarchist is an intermediate perspective balancing short term and long-term impacts that are based on global consensus. The standard perspective, hierarchist, has been assumed in this study. The reference value used to calculate El'99 normalized results is for the European context (environmental impact per year and per capita, considering a population of 386 million for Europe, 1993 year, with some updates [31]).

Recent developments in the LCA methodology emphasize two types of approaches: attributional versus consequential. Attributional LCA (ALCA) focuses on describing the environmentally relevant flows to and from a system, while the Consequential LCA (CLCA) aims to describe how environmentally relevant flows will change in response to possible decisions [36,37]. ALCA generally uses average data for the processes within the system studied and assumes that changes in those processes will not affect the market (background and foreground data). CLCA uses economic and specific market data (marginal data) to study processes within and outside the system that are affected by a change within the system. CLCA has been used to calculate environmental impacts from indirect changes and rebound effects (e.g. land use change) caused by an increased/decreased demand on products or services (minerals, biofuels, agriculture, energy, etc.).

In LCA studies of buildings, the attributional approach (ALCA) is the most commonly used; only a few CLCA studies have been published, namely Vieira and Horvath [38] and Lesage [39,40]. Lesage $[39,40]$ used both ALCA and CLCA to assess brownfield rehabilitation for residential developments and compare it to an exposure minimization scenario, which consists in covering the site with clean soil. Although ALCA results showed no preferable option, CLCA clearly supported rehabilitation of brownfieds for residential reuse in order to avoid the development of suburban sites. With the goal of decreasing uncertainty associated with end-of-life technological forecasting, Vieira and Horvath [38] used both ALCA and CLCA to assess the environmental impacts of concrete used in an office building. They [38] concluded that there is no relevant difference between results from ALCA and CLCA, and that the choice between the use of one or the other for buildings may not be a critical decision. 

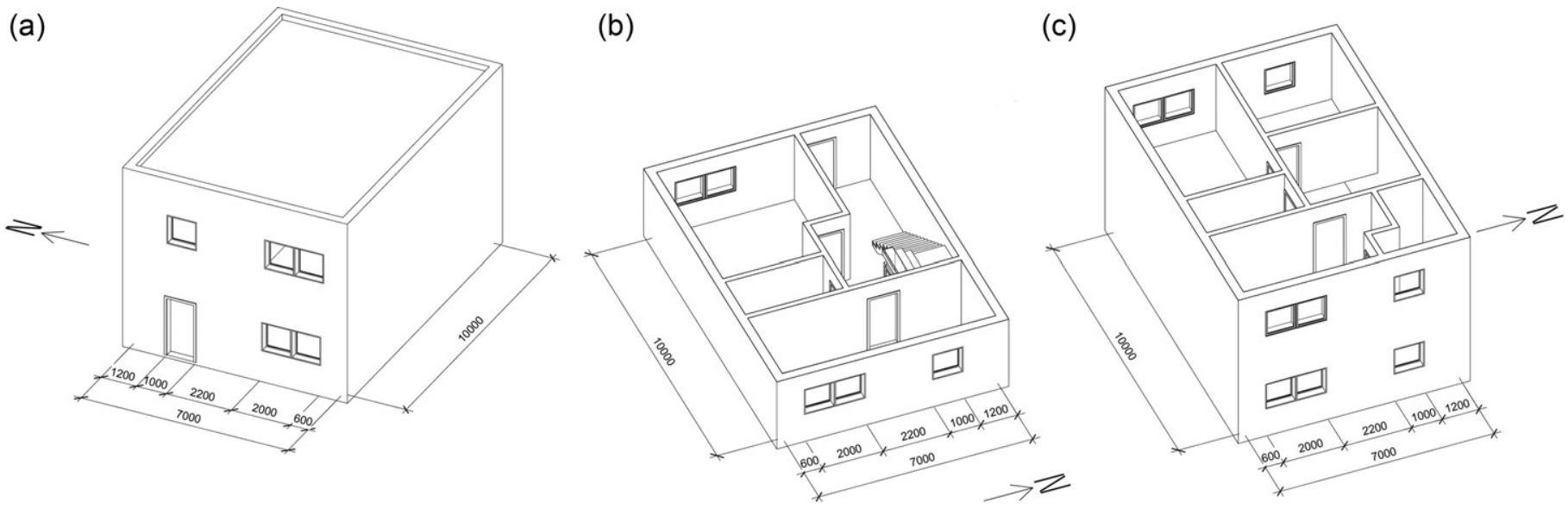

Fig. 1. Architectural model of the single-family house. Axonometric drawings: (a) west view, (b) east view - ground floor section and (c) east view - first floor section.

The ALCA approach has been adopted in this research for two reasons. Firstly, the main aim is to assess seven alternative exterior walls for the same house in order to identify environmentally preferable solutions. Secondly, it was assumed that the occurring changes would not affect the market. The ALCA model and inventory implemented are presented in the next section.

\section{Life-cycle model and inventory for a single-family house}

A life-cycle model has been implemented for a single-family house in Portugal, addressing the most significant building LC phases and processes affected by the seven alternative exterior wall solutions assessed: construction phase (material production and transport processes) and use phase (maintenance, heating, and cooling processes). An ALCA has been implemented, following the main aim of the research and building on research presented in [41-43]. The case study implemented using the Simapro 7 software (www.pre.nl) is based on a basic architecture model (Fig. 1) representing a typical single-family house located in Coimbra, in the center of Portugal, with an expected life span of 50 years and $132 \mathrm{~m}^{2}$ of living area. The functional unit selected is the building living area over the building life span in order to analyze the whole building performance and the various exterior wall house solutions. It has been assumed that the house is occupied by a 4-person family. The two-floor building has a cuboidal shape with a $7 \mathrm{~m} \times 10 \mathrm{~m}$ plan basis and $2.7 \mathrm{~m}$ between slabs, resulting in a total volume of $356 \mathrm{~m}^{3}$. In order to focus on the living area and building exterior walls, no basement, garage and loft have been considered in the model.

\subsection{Construction phase}

The house construction phase includes material production and transportation. To trace the burdens associated with these processes, the building materials have been accounted in terms of mass or volume for the various building components (structure, roof, ground floor, first floor, walls, windows and doors) which are described in Table 2. Construction materials and techniques used in Portugal have been assumed to have a strong thermal inertia level and have been defined to fulfill the Portuguese thermal building regulation requirements [2]. An additional $5 \%$ of materials have been considered to include losses on site due to cutting and fitting processes. These elements have been modeled based on Kellenberger et al. [44], which presents average European LCI data for the production of building materials.

Concerning the exterior walls, seven alternative scenarios have been implemented in the model. The double hollow brick wall solution has been adopted as a base-case (scenario H0), because it is a solution widely used in Portuguese building practice. Table 3 details the seven exterior wall scenarios. The walls considered have different materials in their composition (hollow brick, facing brick, concrete blocks and wood). Different insulation layer thicknesses have been selected in order to obtain similar global thermal coefficients for the various walls ( $U$-values between 0.47 and $\left.0.51 \mathrm{~W} / \mathrm{m}^{2}{ }^{\circ} \mathrm{C}\right)$. Consequently, identical heating and cooling requirements have been assumed for the various scenarios assessed, and thus heating and cooling environmental impacts do not influence the comparison of alternatives.

The transportation of the construction materials to building site has been implemented assuming lorry transportation, with European fleet average characteristics. The inventory data associated with this process were obtained from Spielmann et al. [31] and [45]. The main construction material weights and shipping distances for the alternative exterior walls and common building components are presented in Table 4.

\subsection{Use phase}

The use phase includes heating, cooling and maintenance operational requirements. Following Portuguese building thermal regulation (RCCTE) [2], heating/cooling set-points of $20^{\circ} \mathrm{C} / 25^{\circ} \mathrm{C}$ have been considered as well as $4 \mathrm{~W} / \mathrm{m}^{2}$ of internal heat gains (from lights, electrical appliances and occupants), and a natural ventilation rate of 0.6 air changes per hour. A $10 \mathrm{~kW}$ heat pump with a coefficient of performance (COP) of 2.8 for heating and 2.0 for cooling has been adopted for the house heating and cooling system.

The annual heating and cooling requirements have been calculated using the RCCTE calculation method [2], which is based on a seasonal quasi-steady state method proposed in the European Standard EN ISO 13790 [46]. The RCCTE method assumes a permanent occupancy of the building with interior seasonal setpoints $\left(20^{\circ} \mathrm{C}\right.$ for heating season, $25^{\circ} \mathrm{C}$ for cooling season). For the single-family house of this study, the annual heating and cooling requirements have been quantified as $71.8 \mathrm{kWh} /\left(\mathrm{m}^{2}\right.$ year $)$ for heating and $3.8 \mathrm{kWh} /\left(\mathrm{m}^{2}\right.$ year) for cooling (with a variation of $3 \%$ among the exterior wall house scenarios). However, it should be noted that these are rather unrealistic HVAC levels for Portuguese residential buildings because Portuguese householders are not used to heating/cooling all rooms simultaneously, nor continuously. In fact, this can be confirmed by RCCTE primary energy calculation, which, following the EN ISO 13790 (point 13.2.2), uses a dimensionless reduction factor of 0.1 both for heating and cooling to take into account the intermittent HVAC patterns of Portuguese 
Table 2

Description of base-case building components.

\begin{tabular}{|c|c|c|c|c|c|c|c|}
\hline Building components & Area $\left(m^{2}\right)$ & \multicolumn{2}{|l|}{ Material layers } & Thickness (m) & Volume $\left(\mathrm{m}^{3} / \mathrm{m}^{2}\right)^{*}$ & Weight $\left(\mathrm{kg} / \mathrm{m}^{2}\right)^{*}$ & Total weight $(\mathrm{kg})$ \\
\hline \multirow{8}{*}{ Exterior walls (H0) } & 222 & \multirow{3}{*}{\multicolumn{2}{|c|}{$\begin{array}{l}\text { Masonry: hollow brick }(30 \times 20 \times 11) \\
\text { - Cement mortar } \\
\text { - Water }\end{array}$}} & 0.110 & & 79.90 & 17737.8 \\
\hline & & & & & & 22.00 & 4884.0 \\
\hline & & & & & & 3.30 & 732.6 \\
\hline & 222 & \multicolumn{2}{|c|}{ XPS - extruded polystyrene } & 0.400 & & 1.20 & 266 \\
\hline & 201 & \multirow{3}{*}{\multicolumn{2}{|c|}{$\begin{array}{l}\text { Masonry: hollow brick }(30 \times 20 \times 15) \\
\text { - Cement mortar } \\
\text { - Water }\end{array}$}} & 0.150 & & 107.10 & 21527.1 \\
\hline & & & & & & 30.00 & 6030.0 \\
\hline & & & & & & 4.50 & 904.5 \\
\hline & 184 & \multicolumn{2}{|c|}{ Base plaster } & 0.040 & & 66.00 & 12012.0 \\
\hline \multirow[t]{4}{*}{ Interior walls } & 110 & \multirow{3}{*}{\multicolumn{2}{|c|}{$\begin{array}{l}\text { Masonry: hollow brick }(30 \times 20 \times 11) \\
\text { - Cement mortar } \\
\text { - Water }\end{array}$}} & 0.110 & & 79.90 & 8141.1 \\
\hline & & & & & & 22.00 & 2406.8 \\
\hline & & & & & & 3.30 & 361.0 \\
\hline & & \multicolumn{2}{|l|}{ Base plaster } & 0.040 & & 66.00 & 7220.4 \\
\hline \multirow[t]{8}{*}{ Roof } & 74.4 & \multicolumn{2}{|l|}{ Gravel } & 0.050 & & 90.00 & 6696.0 \\
\hline & & \multicolumn{2}{|l|}{ Felt PP } & 0.002 & & 0.13 & 9.7 \\
\hline & & \multicolumn{2}{|c|}{ XPS - extruded polystyrene } & 0.050 & & 1.50 & 111.6 \\
\hline & & \multicolumn{2}{|c|}{ Bitumen } & 0.010 & & 10.50 & 781.2 \\
\hline & & \multicolumn{2}{|l|}{ Anhydrite screed } & 0.050 & & 50.00 & 3720.0 \\
\hline & & \multicolumn{2}{|l|}{ Concrete C25/30 } & 0.150 & & 360.00 & 26784.0 \\
\hline & & \multicolumn{2}{|c|}{ Reinforced steel $^{* *}$} & & & 12.00 & 892.8 \\
\hline & & \multicolumn{2}{|l|}{ Lime mortar } & 0.02 & & 20.00 & 1488.0 \\
\hline \multirow[t]{6}{*}{ First floor slab } & 76.4 & \multicolumn{2}{|c|}{ Wood floor (planks) } & 0.020 & 0.020 & - & 901.52 \\
\hline & & \multicolumn{2}{|c|}{ Wooden square joist } & 0.040 & 0.003 & - & 134.5 \\
\hline & & \multicolumn{2}{|l|}{ Anhydrite screed } & 0.030 & & 30.00 & 2292.0 \\
\hline & & \multicolumn{2}{|l|}{ Concrete C25/30 } & 0.150 & & 360.00 & 27504.0 \\
\hline & & Reinforced steel & & & & 12.00 & 916.8 \\
\hline & & Lime mortar & & 0.020 & & 20.00 & 1528.0 \\
\hline Ground floor & 80 & Wood planks & & 0.020 & 0.020 & - & 994.0 \\
\hline & & Wooden square & & 0.040 & 0.003 & - & 140.8 \\
\hline & & Lightweight anh & te screed & 0.050 & & 50.00 & 4000.0 \\
\hline & & Concrete $\mathrm{C} 25 / 30$ & & 0.120 & & 288.00 & 23040.0 \\
\hline & & Reinforced steel & & & & 9.60 & 768.0 \\
\hline & & Gravel & & 0.200 & & 360.00 & 28800.0 \\
\hline Building components & & Units & Material layers & & Area/un $\left(\mathrm{m}^{2}\right)^{*}$ & Weight/un (kg/un) & Total weight (kg) \\
\hline Structure & & & & & & & \\
\hline - Beam $(0.3 \times 10 \times C$ & & 6 & Concrete C25/30 & & & 1440.0 & 8640 \\
\hline & & & Reinforced steel ${ }^{*}$ & & & 48.0 & 288 \\
\hline - Column $(6 \times 0.2 \times$ & & 9 & Concrete C25/30 & & & 864.0 & 7776 \\
\hline & & & Reinforced steel ${ }^{*}$ & & & 28.8 & 259 \\
\hline - Foundation $(2 \times 0$ & & 9 & Concrete C25/30 & & & 576.0 & 5184 \\
\hline & & & Reinforced steel $^{*}$ & & & 19.2 & 173 \\
\hline Windows (class III, w & -controlled & 11 & Aluminium fram & & 3.24 & & \\
\hline ventilation devices) & & & Double glazing $(L$ & & 7.95 & & \\
\hline Doors & & 1 & Exterior wooden & & 2.00 & & \\
\hline & & 8 & Interior wooden & & 1.60 & & \\
\hline
\end{tabular}

* " $\mathrm{m} 2$ " represents " $\mathrm{m}^{2}$ of building component".

** $80 \mathrm{~kg} / \mathrm{m}^{3}$ of concrete.

householders. Furthermore, the average annual end-use energy consumption of Portuguese households (2008) is about $2.7 \mathrm{koe} / \mathrm{m}^{2}$ $\left(31 \mathrm{kWh} / \mathrm{m}^{2}\right)$ [47], the lowest level in European. This value is less than half the one calculated by RCCTE. Therefore, in this research two alternative operational patterns (OP) have been considered, based on different occupancy and comfort levels:

- OP1, which represents an intensive occupancy of the house with a medium HVAC level, assumes $50 \%$ of the calculated heating and cooling requirements: $35.9 \mathrm{kWh} /\left(\mathrm{m}^{2}\right.$ year) for heating and $1.9 \mathrm{kWh} /\left(\mathrm{m}^{2}\right.$ year $)$ for cooling;

- OP2, which typifies a moderate occupancy of the house with a modest HVAC level, assumes $10 \%$ of the calculated annual heating and cooling requirements: $7.2 \mathrm{kWh} /\left(\mathrm{m}^{2}\right.$ year $)$ for heating and $0.4 \mathrm{kWh} /\left(\mathrm{m}^{2}\right.$ year $)$ for cooling.

A maintenance activity schedule for each building component has been established based on data from $[14,44,48]$ and material producers. The maintenance activities include interior and exterior painting of walls, varnishing of wood surfaces, window glazing replacement, and bitumen layer fixing. More details can be found in [43].

\subsection{Model simplifications}

Some simplifications have been employed in the LC model. Following the approach implemented in other LC studies with similar purposes $[8,9,16,27]$, the energy requirement of operation-phase activities that are not affected by the exterior wall solution (electric appliances, lighting, cooking, domestic hot water) have not been included. Concerning the construction phase, the equipment used and the transportation of labourers to work site have not been included because the relevance of these processes is minor in residential buildings [9]. The energy and impacts associated with the production and transportation of furniture, HVAC heat distribution equipment, sanitary ceramics and plumbing pipes for 
Table 3

Exterior wall house scenarios with section details.

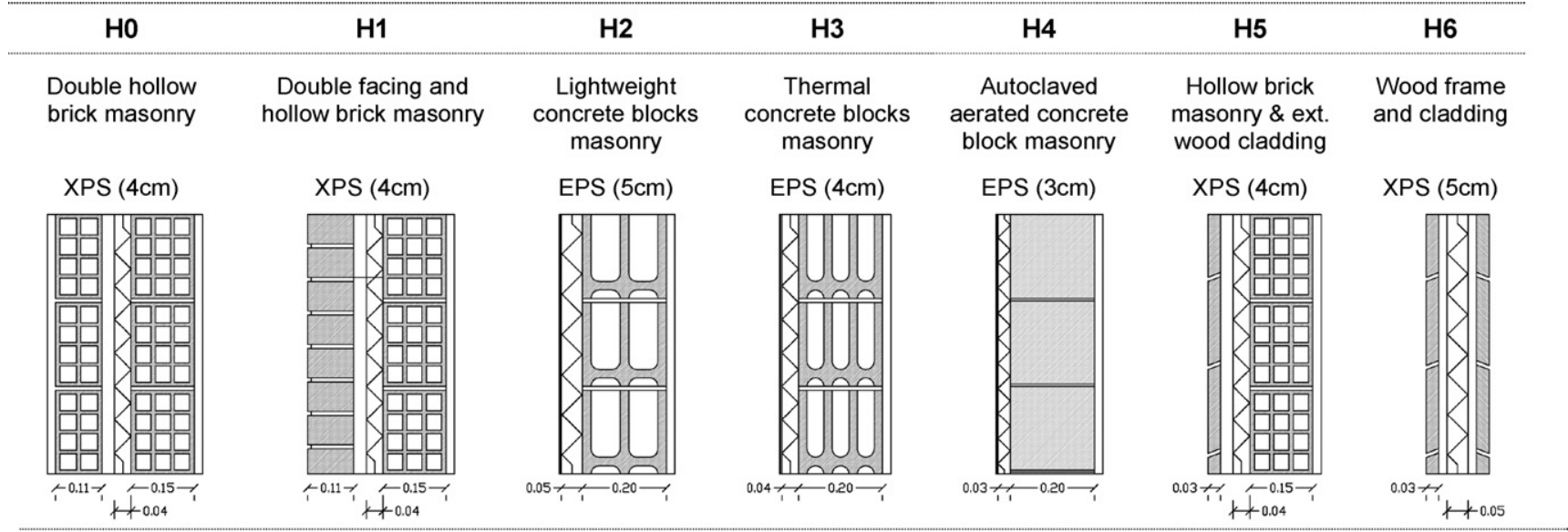

Insulation layer: XPS (extruded polystyrene); EPS (expanded polystyrene).

water consumption have also not been considered. The end-of-life phase (dismantlement and waste treatment scenarios) has not been included because it is considered to be of minor importance for South European single-family houses, and it is a difficult phase to foresee, particularly because buildings are long lasting [6]. According to a recent European study [9], the end-of-life phase accounts for less than 3.2\% of the overall environmental impacts of South European dwellings.

\section{Results and discussion}

In this section, life-cycle primary energy requirement (CED) and environmental results (CML 2001 and Eco-indicator'99) are presented and compared in three parts. Firstly, Section 5.1 shows the base-case house life-cycle impacts for two operational patterns (OP1 and OP2, described in Section 4.2). Five life-cycle processes are characterized: material production and transport; heating; cooling; and maintenance. Secondly, Section 5.2 presents the exterior wall house scenario analysis focusing on the three processes (material production, transport, maintenance) that have different impacts in the various scenarios. Finally, Section 5.3 compares results from the three impact assessment methods.

Table 4

House construction materials: weight and transportation distances.

\begin{tabular}{lrr}
\hline Construction materials & Mass (ton) & Distance $(\mathrm{km})$ \\
\hline Exterior walls & & \\
H0: Brick & 39.26 & 65 \\
H1: Brick & 62.82 & 65 \\
H2: C blocks & 40.86 & 65 \\
H3: TC blocks & 24.73 & 65 \\
H4: AAC block & 24.73 & 65 \\
H5: Wood +brick & 25.19 & 65 \\
H6: Wood & 8.50 & 65 \\
& & \\
Other components & & 65 \\
Brick & 8.74 & 65 \\
Cement mortar & 13.47 & 65 \\
Anhydrite screed & 14.54 & 65 \\
Plaster & 24.28 & 85 \\
XPS/EPS & 0.28 & 170 \\
Gravel & 42.19 & 75 \\
PET & 0.01 & 75 \\
Bitumen & 0.78 & 40 \\
Concrete & 84.23 & 65 \\
Steel & 2.81 & \\
Wood & 2.12 & \\
\hline
\end{tabular}

\subsection{Life-cycle impacts}

5.1.1. Cumulative energy demand results

Fig. 2 presents the CED calculated for the base-case dwelling for two operational patterns (OP1, OP2), and for an additional scenario, RCCTE. Total CED, non-renewable (Non-R) and renewable (Renew) energy requirements are distinguished for each scenario. It should be noted that the RCCTE (100\%) scenario assumes a hypothetical permanent occupancy, and conditioning, of the building with interior seasonal set-points $\left(20^{\circ} \mathrm{C}\right.$ for heating season, $25^{\circ} \mathrm{C}$ for cooling season), without considering any reduction factor to account for intermittent HVAC levels. On the other hand, the two operational patterns, OP1 (50\%) and OP2 (10\%), assume reduction factors to represent different occupancy and comfort levels of Portuguese householders.

As can be seen in Fig. 2, there is an inversion of the most significant LC phase from one operational pattern to the other. The results obtained under OP1 show that the use phase is the most significant due to heating, whereas under OP2, the construction phase has the highest impacts owing to material production. Concerning total OP1 results, heating the house represents $56 \%$ of the total LC

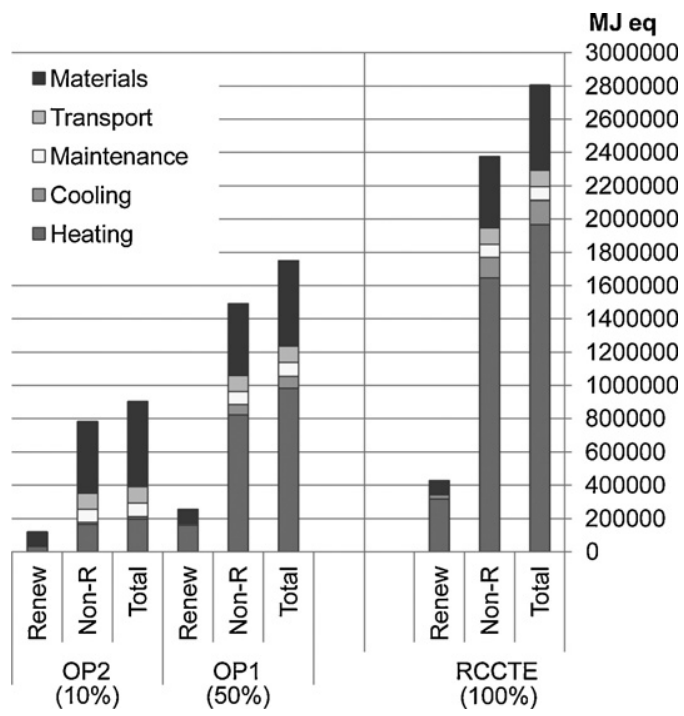

Fig. 2. Life-cycle CED results for base-case house: two operational patterns (OP1 and OP2) and RCCTE. 


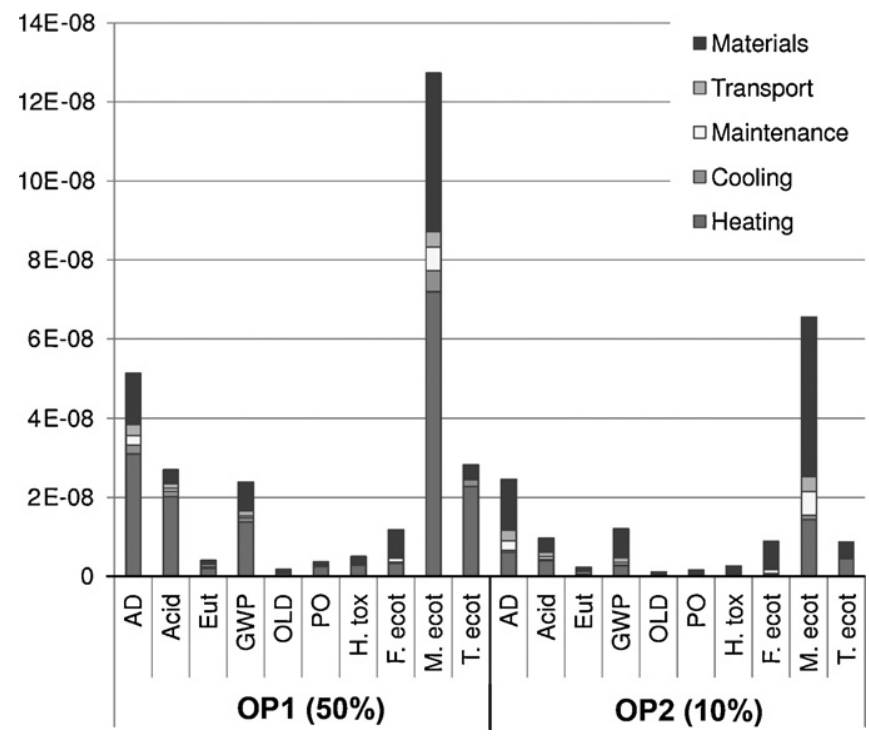

Fig. 3. CML 2001 normalized results for base-case house: two operational patterns (OP1 and OP2).

primary energy requirements (CED), whereas material production holds around $29 \%$, and the remaining processes represent about $5 \%$. However, under OP2, material production represents 56\% of total CED, while heating accounts only for $22 \%$; maintenance and transport become more significant (around 10\%) and cooling decreases its importance (2\%). It can also be observed that the contribution of the different LC processes is very similar for total CED and for non-renewable energy fraction, since the latter has a major role. The single-family house total CED amounts to 1,751,000 MJ equiv. (265 MJ equiv./( $\mathrm{m}^{2}$ year)) under OP1, and around 905,500 MJ equiv. (137 MJ equiv./( $\mathrm{m}^{2}$ year $)$ ) considering OP2. Concerning the RCCTE (100\%) scenario, the primary energy of heating process represents around $70 \%$ of the LC impacts. Moreover, under the RCCTE scenario, the CED of heating is higher than the total CED in OP1. This comparison shows that for the Portuguese context it is critical to consider the intermittent HVAC operational patterns, especially when heating and cooling loads are compared with other LC processes.

\subsubsection{2001 results}

CML 2001 environmental impacts are presented in Table 5 for the various LC processes of the base-case house assuming two operational patterns. Fig. 3 presents CML 2001 normalized results. The inversion found in energy results from OP1 to OP2, between the construction and use phases, is also valid for CML results. Considering OP1, heating is the most significant process in eight out of ten categories (exceptions: OLD and fresh water ecotoxicity), holding around $50 \%$ to $80 \%$ of the environmental impacts. However, in $\mathrm{OP} 2$, material production is the most significant in eight categories (exceptions: acidification and terrestrial ecotoxicity), holding from $48 \%$ to $85 \%$ of the house life-cycle impacts. Concerning OLD impacts, material production is the most significant process under the two operational patterns due to the use of XPS as building envelope insulation.

Regarding total normalized impacts shown in Fig. 3, marine ecotoxicity presents the highest impacts, followed by, in descending order, abiotic depletion, terrestrial ecotoxicity, acidification, GWP, and eutrophication. However, it should be noted that the toxicity categories still lack scientific robustness $[8,32]$, which limits the significance of toxicity results.

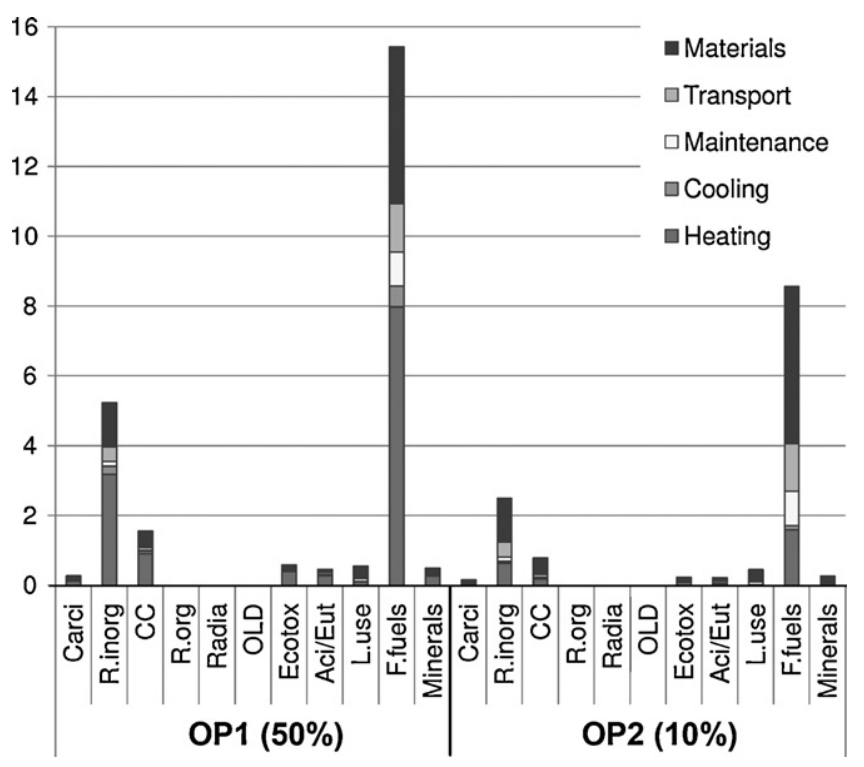

Fig. 4. EI'99 normalized results for base-case house: two operational patterns (OP1 and $\mathrm{OP} 2$ ).

\subsubsection{Eco-indicator'99 results}

The Ecoindicator'99 (El'99) results for the base-case house are given in Table 6 distinguishing the two operational patterns. Fig. 4 shows the EI'99 normalized results. Assuming OP1, heating of the house is the most significant process for seven out of eleven categories, representing 46-69\% of the impacts (exceptions: respiratory organics, radiation, OLD, and land use). Conversely, adopting $\mathrm{OP} 2$, material production becomes the most important process in every category, being responsible for $43-80 \%$ of the environmental impacts of the house. Concerning total EI'99 normalized impacts, fossil fuel is the most significant category, followed by (in descending order) respiratory inorganic and climate change categories.

\subsection{Exterior wall scenario analysis}

\subsubsection{CED results}

Fig. 5 presents the CED results for the seven house scenarios, excluding heating and cooling because these remain constant between scenarios. As can be seen, material production requires significantly more energy than transportation or maintenance. Concerning non-renewable CED, the scenario with lowest energy requirement is the wood wall house (H6). In comparison with the base-case scenario $(\mathrm{HO})$, three scenarios reduce the non-renewable CED (H6, H5, H2) and only one (H1) requires more energy. It can also be noted that there is a significant difference in non-renewable

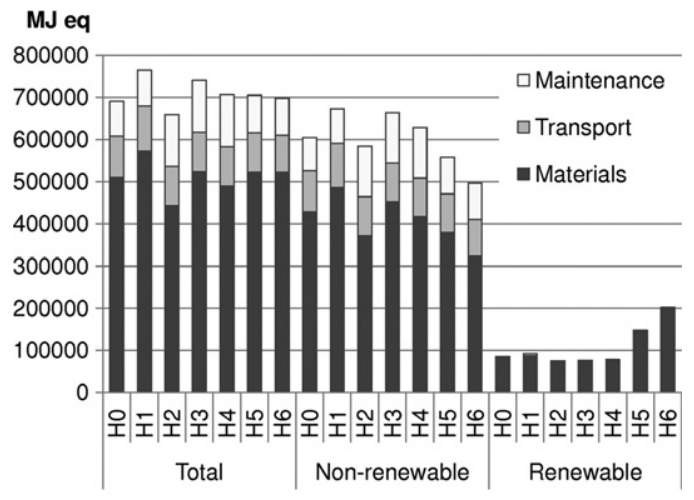

Fig. 5. CED scenario analysis results. 
Table 5

LCIA CML 2011 results for the base-case house, including two alternative operational patterns (OP1 and OP2).

\begin{tabular}{|c|c|c|c|c|c|c|c|c|c|c|}
\hline Life-cycle & AD & Acid & Eut & GWP & OLD & PO & Htox & Fecot & Mecot & Tecot \\
\hline Processes & $\mathrm{kg}$ Sbeq & $\mathrm{kg} \mathrm{SO}_{2} \mathrm{eq}$ & $\mathrm{kg} \mathrm{PO}_{4} \mathrm{eq}$ & $\mathrm{kg} \mathrm{CO}_{2} \mathrm{eq}$ & g CFC-11eq & $\mathrm{kg} \mathrm{C}_{2} \mathrm{H}_{4}$ & $\mathrm{~kg} \mathrm{1,4-DB} \mathrm{eq}$ & $\mathrm{kg} 1,4-\mathrm{DB}$ eq & g 1,4-DB eq & $\mathrm{kg} 1,4-\mathrm{DB}$ eq \\
\hline Materials & 191,38 & 98,28 & 13,65 & 35233 & $\underline{81,8}$ & 7,33 & 12833 & $\underline{3451}$ & 0,457 & 157,0 \\
\hline Transport & 40,97 & 31,70 & 6,84 & 5861 & 0,9 & 1,06 & 998 & 202 & 0,044 & 11,4 \\
\hline Maintenance & 34,63 & 17,18 & 2,75 & 2703 & 0,5 & 0,84 & 1374 & 515 & 0,068 & 13,2 \\
\hline OP1 Heating & $\underline{460,22}$ & $\underline{551,18}$ & $\underline{25,94}$ & $\underline{66317}$ & 63,2 & $\underline{20,56}$ & $\underline{21694}$ & 1685 & $\underline{0,817}$ & $\underline{1075,2}$ \\
\hline OP1 Cooling & 34,11 & 40,84 & 1,92 & 4793 & 3,4 & 1,52 & 1569 & 122 & 0,060 & 79,6 \\
\hline OP2 Heating & 92,04 & 110,24 & 5,19 & 13263 & 12,6 & 4,11 & 4339 & 337 & 0,163 & 215,0 \\
\hline OP2 Cooling & 6,82 & 8,17 & 0,38 & 959 & 0,7 & 0,30 & 314 & 24 & 0,012 & 15,9 \\
\hline \multicolumn{11}{|l|}{ Total LC } \\
\hline OP1 & 761,32 & 739,19 & 51,09 & 114906 & 150,0 & 31,32 & 38467 & 5975 & 1,446 & 1336,4 \\
\hline OP2 & 365,85 & 265,57 & 28,81 & 58018 & 96,6 & 13,65 & 19857 & 4529 & 0,744 & 412,5 \\
\hline
\end{tabular}

Abiotic depletion (AD); acidification (Acid); eutrophication (Eut); ozone layer depletion (OLD); photochemical oxidation (PO); human toxicity (Htox); Fresh water ecotoxicity (Fecot.); marine ecotoxicity (Mecot.); terrestrial ecotoxicity (Tecot.). The highest values for each impact category have their results underlined (continuous line for OP1, dashed line for OP2).

CED results between the various house scenarios: H6 requires $176,350 \mathrm{MJ}$ equiv. less than $\mathrm{H} 1$ (a reduction of about 26\%). This variation is mostly due to material production CED. On the other hand, the scenarios with higher wood content (H6, H5) have more renewable energy incorporated in the material production, since wood is considered a renewable source of energy.

\subsubsection{2001 results}

CML 2001 LCIA results for the various house scenarios are presented in Table 7, and normalized LCIA results are shown in Fig. 6. It can be observed that the scenario with the lowest environmental impact is the wood wall house (H6), in nine out of ten categories. On the other hand, the scenarios with highest environmental impacts are H3 (five categories), H1 (GWP and abiotic depletion) and H4 (two ecotoxicity categories).

The comparison with the base-case house (HO) shows that three scenarios ( $\mathrm{H} 2, \mathrm{H} 5$, and $\mathrm{H} 6$, in descending order) have significantly lower impacts for GWP, abiotic depletion, acidification and eutrophication categories. Concerning photochemical oxidation, only H5 and H6 have lower impacts than H0. Regarding OLD, H6 has the highest impact, which is due to the type and thickness of the insulation material assumed (XPS); the scenarios with lower impacts are those with EPS insulation applied within ETICS $(\mathrm{H} 2, \mathrm{H} 3$ and H4). Looking at the results category by category, the following relative variations between the scenarios with the lowest and highest impacts have been determined based on LC data presented in Fig. 6:

- Abiotic depletion: H6 has 27\% less Sb equiv. than H1;

- Acidification: $\mathrm{H} 6$ has $38 \%$ less $\mathrm{SO}_{2}$ equiv. than $\mathrm{H} 3$;

- Eutrophication: $\mathrm{H} 6$ has $21 \%$ less $\mathrm{PO}_{4}$ equiv. than $\mathrm{H} 3$;

- GWP: $\mathrm{H} 6$ has $58 \%$ less $\mathrm{CO}_{2}$ equiv. than $\mathrm{H} 1$;

- OLD: H2, H3 and H4 have 58\% less CFC-11 equiv. than H6;

- Photochemical oxidation: $\mathrm{H} 6$ has $37 \%$ less $\mathrm{C}_{2} \mathrm{H}_{4}$ equiv. than $\mathrm{H} 3$.

\subsubsection{Eco-indicator'99 results}

EI'99 LCIA results for the seven scenarios are presented in Table 8. Normalized LCIA results are shown in Fig. 7. Regarding the scenario with the lowest environmental impacts, similar results to the CML approach can be observed: the wood wall scenario (H6) performs better in nine out of eleven categories. The scenarios with the highest environmental impacts are $\mathrm{H} 1$ (four categories), $\mathrm{H} 3$ (three categories), H4 and H6 (two categories for each one). The comparison with the base-case scenario shows that the scenarios

Table 6

LCIA El'99 results for the base-case house, including two operational patterns (OP1 and OP2).

\begin{tabular}{|c|c|c|c|c|c|c|c|c|c|c|c|}
\hline \multirow{2}{*}{$\begin{array}{l}\text { Life-cycle } \\
\text { Processes }\end{array}$} & \multicolumn{6}{|c|}{$\begin{array}{c}\text { Human Heath } \\
\text { (DALY) }\end{array}$} & \multicolumn{3}{|c|}{$\begin{array}{c}\text { Ecosystem Quality } \\
\left(\mathrm{PDF}^{*} \mathrm{~m}^{2} \cdot \mathrm{y}\right)\end{array}$} & \multicolumn{2}{|c|}{$\begin{array}{l}\text { Ressources } \\
\quad(\mathrm{MJ} \text { eq) }\end{array}$} \\
\hline & Carci & $\mathrm{CC}$ & OLD & Radation & R.inorg & R.org & Acid/Eut & Ecot & LUse & F.Fuels & Minerals \\
\hline Materials & $1,64 \mathrm{E}-03$ & $\underline{8,65 \mathrm{E}-05}$ & $\underline{7.51 \mathrm{E}-05}$ & $1,93 \mathrm{E}-02$ & $7,32 \mathrm{E}-03$ & $\underline{1,25 \mathrm{E}-04}$ & $5,81 \mathrm{E}+02$ & $4.82 \mathrm{E}+02$ & $\underline{1,69 \mathrm{E}+03}$ & $3.78 \mathrm{E}+04$ & $1,51 \mathrm{E}+03$ \\
\hline Transport & $1,15 \mathrm{E}-04$ & $9,60 \mathrm{E}-07$ & $9,75 \mathrm{E}-06$ & $6,48 \mathrm{E}-03$ & $1,23 \mathrm{E}-03$ & $1,53 \mathrm{E}-05$ & $1,23 \mathrm{E}+02$ & $2,86 \mathrm{E}+02$ & $1,29 \mathrm{E}+02$ & $1,16 \mathrm{E}+04$ & $8,21 \mathrm{E}+01$ \\
\hline Maintenance & $3,18 \mathrm{E}-04$ & $5,60 \mathrm{E}-07$ & $4,23 \mathrm{E}-06$ & $2,05 \mathrm{E}-03$ & $5,67 \mathrm{E}-04$ & $1,65 \mathrm{E}-05$ & $6,49 \mathrm{E}+01$ & $5,54 \mathrm{E}+01$ & $3,92 \mathrm{E}+02$ & $8,20 \mathrm{E}+03$ & $1,56 \mathrm{E}+02$ \\
\hline OP1 Heating & $\underline{1,92 \mathrm{E}-03}$ & $6,68 \mathrm{E}-05$ & $2,07 \mathrm{E}-05$ & $\underline{4,89 \mathrm{E}-02}$ & $\underline{1,39 \mathrm{E}-02}$ & $2,33 \mathrm{E}-05$ & $\underline{2,07 \mathrm{E}+03}$ & $\underline{1,44 \mathrm{E}+03}$ & $5,53 \mathrm{E}+02$ & $\underline{6,71 \mathrm{E}+04}$ & $\underline{2.22 \mathrm{E}+03}$ \\
\hline OP1 Cooling & $1,36 \mathrm{E}-04$ & $3,63 \mathrm{E}-06$ & $1,53 \mathrm{E}-06$ & $3,62 \mathrm{E}-03$ & $1,00 \mathrm{E}-03$ & $1,67 \mathrm{E}-06$ & $1,51 \mathrm{E}+02$ & $1,07 \mathrm{E}+02$ & $4,07 \mathrm{E}+01$ & $4,97 \mathrm{E}+03$ & $1,52 \mathrm{E}+02$ \\
\hline OP2 Heating & $3,83 \mathrm{E}-04$ & $1,34 \mathrm{E}-05$ & $4,14 \mathrm{E}-06$ & 9,78E-03 & $2,77 \mathrm{E}-03$ & $4,67 \mathrm{E}-06$ & $4,15 \mathrm{E}+02$ & $2,88 \mathrm{E}+02$ & $1,11 \mathrm{E}+02$ & $1,34 \mathrm{E}+04$ & $4,44 \mathrm{E}+02$ \\
\hline OP2 Cooling & $2,72 \mathrm{E}-05$ & $7,25 \mathrm{E}-07$ & $3,06 \mathrm{E}-07$ & $7,23 \mathrm{E}-04$ & $2,00 \mathrm{E}-04$ & $3,33 \mathrm{E}-07$ & $3,02 \mathrm{E}+01$ & $2,14 \mathrm{E}+01$ & $8,14 \mathrm{E}+00$ & $9,94 \mathrm{E}+02$ & $3,04 \mathrm{E}+01$ \\
\hline \multicolumn{12}{|l|}{ Total LC } \\
\hline OP1 & $4,12 \mathrm{E}-03$ & $1,58 \mathrm{E}-04$ & $1,11 \mathrm{E}-04$ & $8,03 \mathrm{E}-02$ & $2,40 \mathrm{E}-02$ & $1,81 \mathrm{E}-04$ & $2,99 \mathrm{E}+03$ & $2,37 \mathrm{E}+03$ & $2,80 \mathrm{E}+03$ & $1,30 \mathrm{E}+05$ & $4,12 \mathrm{E}+03$ \\
\hline OP2 & $2,48 \mathrm{E}-03$ & $1,02 \mathrm{E}-04$ & $9,35 \mathrm{E}-05$ & $3,83 \mathrm{E}-02$ & $1,21 \mathrm{E}-02$ & $1,61 \mathrm{E}-04$ & $1,21 \mathrm{E}+03$ & $1,13 \mathrm{E}+03$ & $2,33 \mathrm{E}+03$ & $7,20 \mathrm{E}+04$ & $2,22 \mathrm{E}+03$ \\
\hline
\end{tabular}

Carcinogens (Carci); climate change (CC); ozone layer depletion (OLD); radiation; respiratory inorganics (R. inorg); respiratory organics (R. org.); acidification-eutrophication (acid/eut); ecotoxicity (Ecot); land use (L. use); fossil fuels (F. fuels). The highest values for each impact category have their results underlined (continuous line for OP1, dashed line for OP2). 
with wood in their composition ( $\mathrm{H} 5$ and $\mathrm{H} 6$ ) have lower impacts for nine categories (except land use and OLD). H2 has lower impacts than base-case for five categories, and $\mathrm{H} 4$ for three categories (OLD, respiratory organics and land use). Concerning the land use category, wood wall house (H6) has the highest impacts because of land use change due to logging. However, this high impact is debatable if logging is based on a sustainable forest management strategy.

Eco-indicator'99 normalized results have been further grouped in three damage categories: resources; ecosystem quality; and human health. H6 is the scenario with lowest impacts in resources and human health but with highest impacts in ecosystem quality (due to land use impact category results). Scenario $\mathrm{H} 4$ has the lowest impacts in ecosystem quality. Assessing the El'99 results, category by category, the following variations between the scenarios with the lowest and highest impacts have been determined:

- Fossil fuels: H6 has 31\% less MJ surplus than H1;

- Minerals: H6 has 14\% less MJ surplus than H3;

- Acidification/eut.: H6 has 27\% less PDF than H1, H3;

- Climate change: H6 has 59\% less DALY than H1;

- Ozone layer: H2 has 58\% less DALY than H6;

- Resp. organics: H6 has 9\% less DALY than H1;

- Carcinogens: H6 has 9\% less DALY than H4;

- Radiation: H6 has 21\% less DALY than H4;

- Resp. inorganics: H6 has 23\% less DALY than H3;

- Ecotoxicity: H6 has 12\% less PDF than H3;

- Land use: H4 has 68\% less PDF than H6;

- Resources: H6 has 30\% less MJ surplus than H1;

- Ecosystem quality: H4 has 52\% less PDF than H6;

- Human health: H6 has 28\% less DALY than H1.

\subsection{Comparing the three impact assessment methods}

The three LCIA methods used in this study have very different approaches. CED is a single-issue method accounting only for primary energy requirements. The two others are environmental LCIA methods: CML 2001 is problem-oriented and El'99 is damageoriented. In general, the three methods indicate that the most important LC phase and process depend on the operational pattern assumed. As presented in Section 5.1, when heating and cooling loads are reduced, the use phase impact is decreased and the preuse processes become relatively more important, mainly due to material production.

However, a more detailed assessment, at the individual category level, shows some important differences. Namely, CML results present higher impacts for the use phase, while those of El'99 are higher for material production. For example, considering OP1, the heating is responsible for more than $50 \%$ of the impacts for eight CML categories, but only for six El'99 categories. Concerning OP2, material production is the most significant process for all EI'99 categories, but only for eight out of ten CML categories. The comparison of CML and El'99 normalized results (Figs. 3 and 4) shows that the most significant category for El'99 is fossil fuels, whereas for CML it is marine ecotoxicity. The second most significant El'99 category is respiratory inorganics, while for $\mathrm{CML}$ it is abiotic depletion. It can be concluded that normalized EI'99 and CML results, in general, will lead to different results in terms of the most significant categories.

Concerning the exterior wall scenario analysis, the three methods indicate the same scenario with the best (energy and environmental) performance. The results show that the wood wall scenario (H6) has the lowest impacts for almost all categories (ozone layer depletion and land use are the exceptions). To determine in detail the extent to which the results of our study are influenced by the LCIA method chosen, similar categories of the three LCIA methods have been comprehensively assessed for the

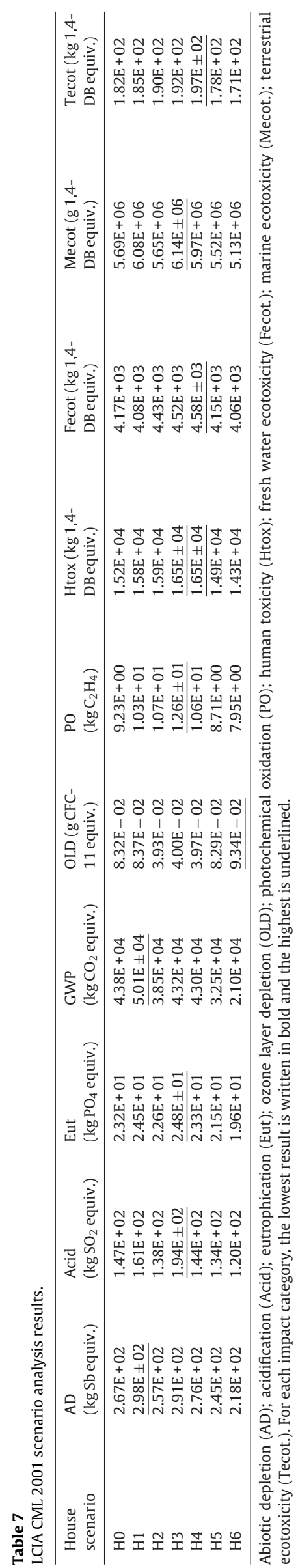




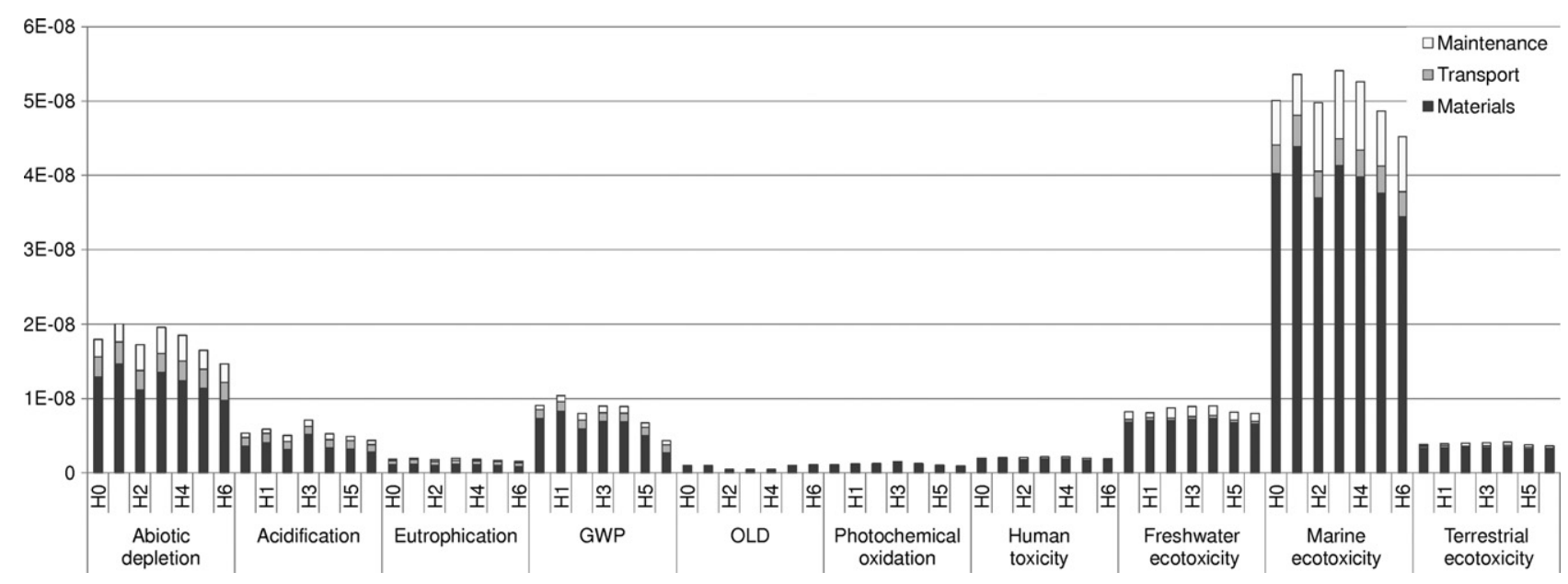

Fig. 6. CML 2001 normalized results: scenario analysis.

Table 8

LCIA El'99 scenario analysis results.

\begin{tabular}{|c|c|c|c|c|c|c|c|c|c|c|c|}
\hline \multicolumn{7}{|c|}{ HouseHuma } & \multicolumn{3}{|c|}{ Ecosystem quality $\left(\mathrm{PDF}^{*} \mathrm{~m}^{2} \mathrm{y}\right)$} & \multicolumn{2}{|c|}{ Resources (MJ) } \\
\hline & Carci & CC & OLD & Radiation & R. inorg. & R. org. & Acid/eut. & Ecot. & L. use & F. fuels & Minerals \\
\hline HO & $2.07 \mathrm{E}-03$ & $9.12 \mathrm{E}-03$ & $8.80 \mathrm{E}-05$ & $1.56 \mathrm{E}-04$ & $2.78 \mathrm{E}-02$ & $8.91 \mathrm{E}-05$ & $8.23 E+02$ & $7.68 \mathrm{E}+02$ & $2.21 \mathrm{E}+03$ & $5.76 \mathrm{E}+04$ & $1.75 E+03$ \\
\hline $\mathrm{H} 1$ & $2.04 \mathrm{E}-03$ & $1.04 E-02$ & $8.85 E-05$ & $1.66 \mathrm{E}-04$ & $3.01 \mathrm{E}-02$ & $9.51 \mathrm{E}-05$ & $9.18 \mathrm{E} \pm 02$ & $7.86 \mathrm{E}+02$ & $2.05 E+03$ & $6.54 \mathrm{E} \pm 04$ & $1.81 \mathrm{E}+03$ \\
\hline H3 & $2.12 \mathrm{E}-03$ & $9.02 \mathrm{E}-03$ & $4.26 E-05$ & $1.60 \mathrm{E}-04$ & $3.13 E-02$ & $9.26 \mathrm{E}-05$ & $8.88 \mathrm{E}+02$ & $8.31 \mathrm{E} \pm 02$ & $1.99 \mathrm{E}+03$ & $6.47 \mathrm{E}+04$ & $1.94 \mathrm{E} \pm 03$ \\
\hline $\mathrm{H} 4$ & $2.13 \mathrm{E}-03$ & $8.98 \mathrm{E}-03$ & $4.24 E-05$ & $1.73 E-04$ & $\overline{2.79 \mathrm{E}-02}$ & $8.90 \mathrm{E}-05$ & $7.96 \mathrm{E}+02$ & $\overline{8.23 E+02}$ & $1.90 \mathrm{E}+03$ & $5.84 \mathrm{E}+04$ & $\overline{1.93 \mathrm{E}+03}$ \\
\hline H5 & $1.99 \mathrm{E}-03$ & $6.74 \mathrm{E}-03$ & $8.77 \mathrm{E}-05$ & $1.50 \mathrm{E}-04$ & $2.62 \mathrm{E}-02$ & $8.83 E-05$ & $7.53 E+02$ & $7.57 \mathrm{E}+02$ & $4.01 E+03$ & $5.19 \mathrm{E}+04$ & $1.74 \mathrm{E}+03$ \\
\hline $\mathrm{H} 6$ & $1.94 \mathrm{E}-03$ & $4.32 E-03$ & $9.88 \mathrm{E}-05$ & $1.38 E-04$ & $2.42 \mathrm{E}-02$ & $8.68 E-05$ & $6.71 E+02$ & $7.33 E+02$ & $5.87 \mathrm{E} \pm 03$ & $4.51 E+04$ & $1.68 \mathrm{E}+03$ \\
\hline
\end{tabular}

Carcinogens (Carci); climate change (CC); ozone layer depletion (OLD); radiation; respiratory inorganics (R. inorg.); respiratory organics (R. org.); acidification-eutrophication (Acid/Eut); ecotoxicity (Ecot.); land use (L. use); fossil fuels (F. fuels). For each impact category, the lowest result is written in bold and the highest is underlined.

scenario analysis performed. Fig. 8 compares the results of the exterior wall house scenarios for each set of similar impact categories. Each graph presents the impacts of the various scenarios relatively (as a percentage) to the scenario with the highest impact (100\%).

It can be seen in Fig. 8 that non-renewable CED, abiotic depletion (CML), and resources (El'99) show similar results. Furthermore, the GWP and OLD CML categories have identical results to their counterpart El'99 categories (climate change and ozone layer).
Acidification and eutrophication are two distinct categories in CML but just one in EI'99 (see Table 1). In general, an analogous ordering of scenario impacts can be observed in CML and EI'99, but El'99 results are more close to CML acidification results. Regarding ecotoxicity, photochemical oxidation and human toxicity, H6 is the scenario with lowest impacts in both CML and El'99. However, the scenario with the highest impact and the ranking of the remaining scenarios differ for the two methods.

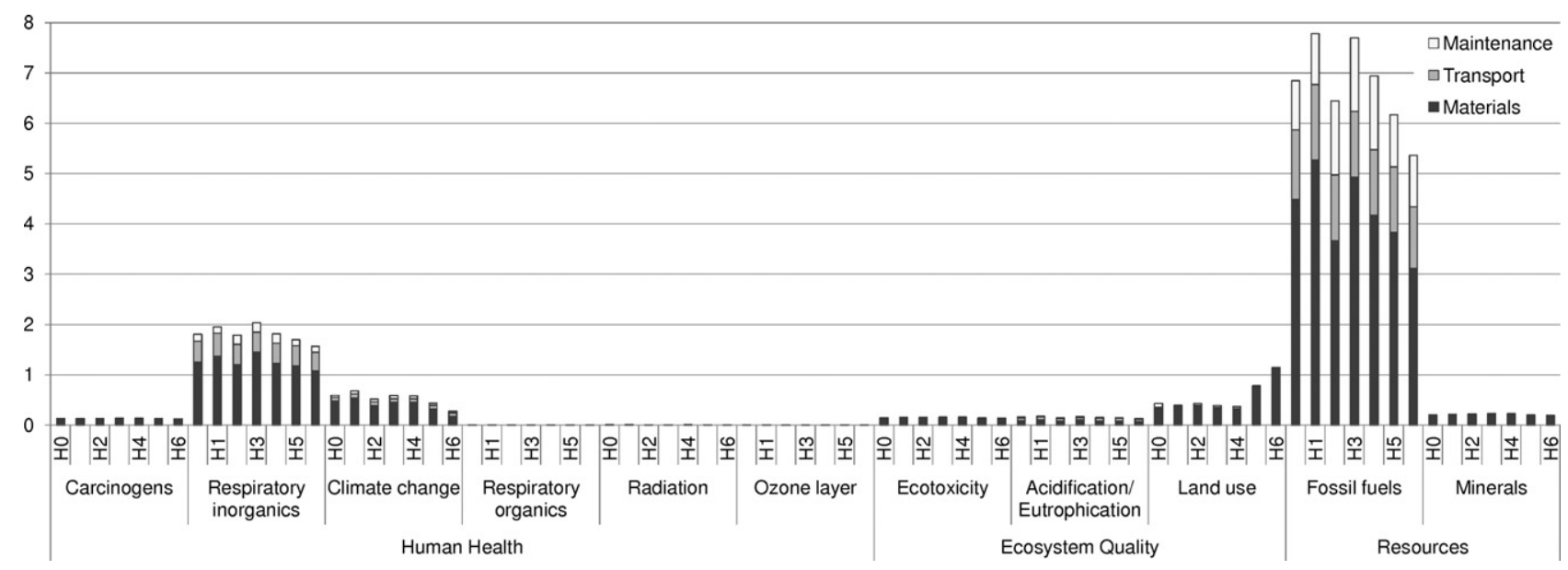

Fig. 7. El'99 normalized results: scenario analysis. 

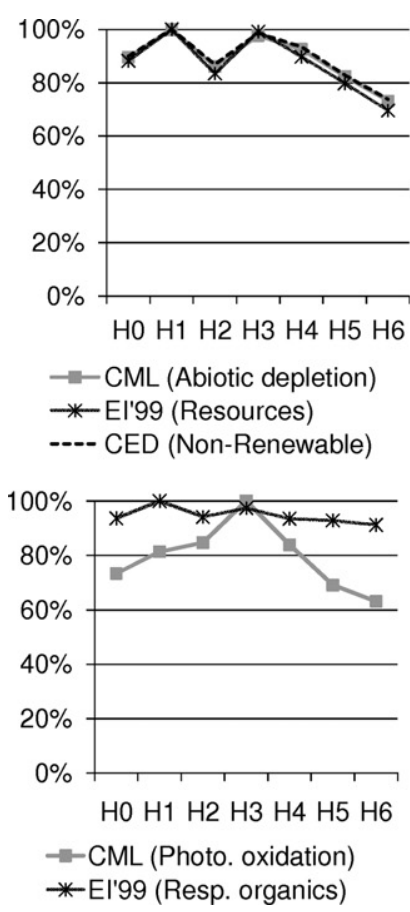
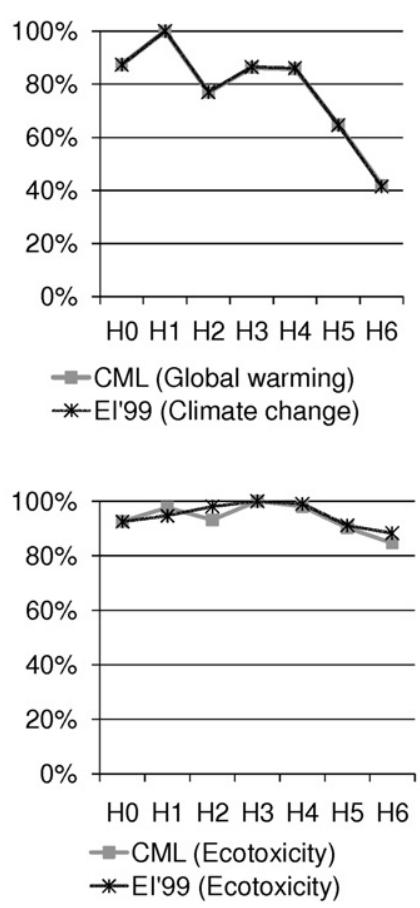
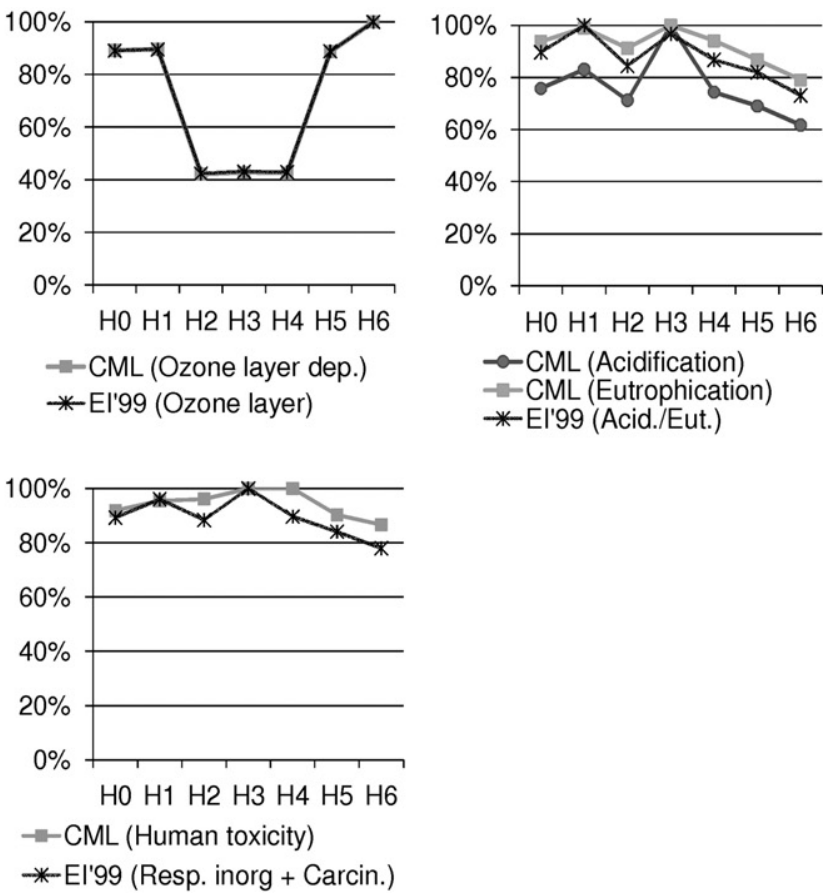

Fig. 8. Relative comparison of CED, CML and El'99 similar categories: scenario analysis results.

Comparing non-renewable CED with the two other LCIA methods (multi-category), it can be seen that, beyond being similar to abiotic depletion and resources, non-renewable CED shows some correlation with GWP and Climate Change as well as with acidification/eutrophication. However, no correlation can be seen between CED and the remaining CML and El'99 impact categories. This can be explained because GWP, acidification and eutrophication impacts in this research are mainly associated with fossil energy use, which is characterized by CED non-renewable results. Concerning the comparison between the two LCIA multi-category methods (CML and El'99), GWP and OLD categories show the most robust comparison of results, being followed by abiotic depletion, acidification and eutrophication. Nevertheless, CML and El'99 methods can present inconsistent results between similar categories (different ranking), which ultimately can influence the choice between solutions.

\section{Conclusions}

A life-cycle model has been implemented for a Portuguese single-family house focusing on the life-cycle (LC) phases and processes affected by the building envelope solutions (material production and transport, heating, cooling, maintenance) to determine the various associated energy and environmental impacts. Seven exterior wall house scenarios with different materials in their composition (hollow brick, facing brick, concrete blocks, wood) have been comparatively assessed in order to support the selection of more sustainable exterior walls. Two operational patterns have been considered to represent distinct occupancy patterns and comfort levels of the house. To assess the building LC performance and the seven scenarios, three life-cycle impact assessment (LCIA) methods have been used: (i) cumulative energy demand (CED); (ii) CML 2001; (iii) Eco-indicator'99 (El'99). A comparison of the LCIA methods has been performed to determine to what extent the LCA results are influenced by the method applied.

The results calculated for the three LCIA methods show that the most significant LC phase and process are highly associated with the house operational patterns: for Portuguese houses with reduced
HVAC levels, material production becomes the most important process. This finding contradicts most of the previous LCA studies for conventional buildings, because these studies have been performed for cold climates, assuming permanent occupancy and high comfort levels. Moreover, for the Portuguese context it is critical to consider the intermittent HVAC operational patterns, especially when heating and cooling loads are compared with other LC processes. Concerning the exterior wall scenario analysis, the three LCIA methods indicate that H6 (wood wall) is the preferable solution with the lowest impacts for most categories, whereas the alternatives with higher impacts are $\mathrm{H} 1$ (double wall with facing brick), H3 (thermal concrete block wall) and H4 (autoclaved aerated concrete block masonry).

Regarding the comparison of results from the three LCIA methods, an analogous ranking of exterior wall alternatives is observed for non-renewable CED, abiotic depletion(CML 2001) and resources (El'99). Non-renewable CED results also present some correlation with CML 2001 and El'99 for two sets of homologous categories: GWP/climate change; acidification and eutrophication. However, no correlation can be seen with the remaining LCIA impact categories. Concerning CML 2001 and El'99 environmental impacts, the results for most categories are robust and permit a straightforward comparison. Nevertheless, these methods present inconsistent results for human toxicity, eco-toxicity and photochemical oxidation, namely a different ranking of the alternative walls, which ultimately can influence the choice among solutions. In addition, further divergences have been observed between CML 2001 and EI'99, namely between the most significant normalized categories (fossil fuels for EI'99, marine ecotoxicity for CML) and results (CML presents slightly higher impacts for the use phase, while El'99 for material production).

To sum up, although the wood wall has been pointed out as the preferable solution by the three methods, the results for the remaining exterior wall scenarios are influenced by the LCIA method applied, in particular for the toxicity categories. Our research reinforces the idea that decision-making based on the LCA of dwellings should include multiple environmental impacts, but should not address toxicity categories. 


\section{Acknowledgements}

Helena Monteiro is grateful for the financial support provided by FCT (Portuguese Science and Technology Foundation), under the program MIT Portugal - Sustainable Energy Systems, through the doctoral degree grant SFRH/BD/33736/2009. Support from the FCT in the scope of the following projects is also acknowledged: PTDC/TRA/72996/2006; MIT/SET/0014/2009; MIT/MCA/0066/2009; and PTDC/SEN-TRA/117251/2010. We thank the anonymous reviewers for their comments, which helped improve this article. We also thank MIT Writing and Communication Center for the help on matters of clarity.

\section{References}

[1] EPBD, Directive 2002/91/EC of the European Parliament and of the Council of 16 December 2002 on the energy performance of buildings, Official Journal of the European Union (2002), L1/65-1/71.

[2] RCCTE, Regulamento das Características de Comportamento Térmico dos Edifícios, Code of the Buildings Thermal Behaviour Characteristics - DL80/2006, Ministry of Public Works, Transportation and Communications, 2468-2513, 2006

[3] EPBD (recast), Directive2010/31/EU of the European Parliament and of the Council of 19 May 2010 on the energy performance of buildings (recast), 2010, pp. L153/13-153/35.

[4] G. Blengini, T. Di Carlo, The changing role of life cycle phases, subsystems and materials in the LCA of low energy buildings, Energy and Buildings 42 (6) (2010) 869-880.

[5] S. Citherlet, T. Defaux, Energy and environmental comparison of three variants of a family house during its whole life span, Building and Environment 42 (2007) 591-598.

[6] B. Peuportier, Life cycle assessment applied to the comparative evaluation of single family houses in the French context, Energy and Buildings 33 (5) (2001) 443-450.

[7] O. Ortiz, J.C. Pasqualino, G. Díez, F. Castells, The environmental impact of the construction phase: an application to composite walls from a life cycle perspective, Resources Conservation and Recycling 54 (2010) 832-840.

[8] F. Nemry, A. Uihlein, C.M. Colodel, C. Wetzel, A. Braune, B. Wittstock, I. Hasan, J. Kreißig, N. Gallon, S. Niemeier, Options to reduce the environmental impacts of residential buildings in the European Union - potential and costs, Energy and Buildings 42 (7) (2010) 976-984.

[9] F. Nemry, A. Uihlein, C.M. Colodel, B. Wittstock, A. Braune, C. Wetzel, I. Hasan, S. Niemeier, Y. Frech, Environmental Improvement Potentials of Residential Buildings (IMPRO-Building), Report JRC:EUR 23493 EN, Luxembourg, 2008.

[10] C.D. Frenette, C. Bulle, R. Beauregard, A. Salenikovich, D. Derome, Using life cycle assessment to derive an environmental index for light-frame wood wall assemblies, Building and Environment 45 (2010) 2111-2122.

[11] L.C. Dreyer, A.L. Niemann, M. Hauschild, Comparison of three different LCIA methods: EDIP 97, CML 2001 and Eco-indicator 99, International Journal LCA 8 (4) (2003) 191-200.

[12] K. Adalberth, Energy use during the life cycle of single-unit dwellings: examples, Building and Environment 32 (4) (1997) 321-329.

[13] K. Adalberth, Energy use during the life cycle of buildings: a method, Building and Environment 32 (4) (1997) 317-320.

[14] S. Blanchard, P. Reppe, Life cycle analysis of a residential home in Michigan, Center for Sustainable Systems, Ann Arbor, MI, Report No. CSS98-05, University of Michigan, 1998.

[15] G.A. Keoleian, S. Blanchard, P. Reppe, Life-cycle energy costs and strategies for improving a single-family house, Journal of Industrial Ecology 4 (2001) 135-156.

[16] I.Z. Bribián, A.A. Usón, S. Scarpellini, Life cycle assessment in buildings: stateof-the-art and simplified LCA methodology as a complement for building certification, Building and Environment 44 (2009) 2510-2520.

[17] L. Gustavsson, A. Joelsson, Life cycle primary energy analysis of residential buildings, Energy and Buildings 42 (2010) 210-220.

[18] L. Gustavsson, A. Joelsson, R. Sathre, Life cycle primary energy use and carbon emission of an eight-storey wood-framed apartment building, Energy and Buildings 42 (2010) 230-242.

[19] J.N. Hacker, T.P. De Saulles, A.J. Minson, M.J. Holmes, Embodied and operational carbon dioxide emissions from housing: a case study on the effects of thermal mass and climate change, Energy and Buildings 40 (2008) 375-384

[20] A. Mahdavi, E.M. Doppelbauer, A performance comparison of passive and lowenergy buildings, Energy and Buildings 42 (2010) 1314-1319.
[21] C. Thormark, A low energy building in a life cycle, its embodied energy, energy need for operation and recycling potential, Building and Environment 37 (2002) 429-435.

[22] A. Utama, S. Gheewala, Life cycle energy of single landed houses in Indonesia, Energy and Buildings 40 (2008) 1911-1916.

[23] I. Sartori, A.G. Hestnes, Energy use in the life cycle of conventional and lowenergy buildings: a review article, Energy and Buildings 39 (3)(2007)249-257.

[24] O. Ortiz, F. Castells, G. Sonnemann, Sustainability in the construction industry: a review of recent developments based on LCA, Construction and Building Materials 23 (2009) 28-39.

[25] T. Ramesh, R. Prakash, K.K. Shukla, Life cycle energy analysis of buildings: an overview, Energy and Buildings 42 (10) (2010) 1592-1600.

[26] A. Sharma, A. Saxena, M. Sethi, V. Shree, Life cycle assessment of buildings: a review, Renewable and Sustainable Energy Reviews 15 (2011) 871-875.

[27] G. Verbeeck, H. Hens, Life cycle inventory of buildings: a contribution analysis, Building and Environment 45 (2010) 964-967.

[28] ISO-14040, ISO 14040, Environmental Management - Life Cycle Assessment Principles and Framework, 2006.

[29] ISO-14044, ISO 14044, Environmental Management - Life Cycle Assessment Requirements and Guidelines, 2006.

[30] J. Malça, F. Freire, Renewability and life-cycle energy efficiency of bioethanol and bio-ethyl tertiary butyl ether (bioETBE): assessing the implications of allocation, Energy 31 (15) (2006) 3362-3380.

[31] R. Frischknecht, N. Jungbluth, H.J. Althaus, G. Doka, R. Dones, R. Hischier, S. Hellweg, S. Humbert, M. Margni, T. Nemecek, M. Spielmann, Implementation of life cycle impact assessment methods: data v2.0, Ecoinvent report No. 3, Dübendorf, $\mathrm{CH}, 2007$.

[32] L. Barnthouse, J. Fava, K. Humphreys, R. Hunt, L. Laibson, S. Noesen, G. Norris, J. Owens, J. Todd, B. Vigon, K. Weitz, J. Young, Life cycle impact assessment: the state-of-the-art, SETAC Press, FL, 1998.

[33] J.B. Guinée, M. Gorrée, R. Heijungs, G. Huppes, R. Kleijn, A. de Koning, L. van Oers, A. Wegener Sleeswijk, S. Suh, H.A. Udo de Haes, H. de Bruijn, R. van Duin, M.A.J. Huijbregts, Handbook on Life Cycle Assessment - Operational Guide to the ISO Standards. I. LCA in Perspective; Ila: Guide; IIb: Operational Annex III: Scientific Background, Kluwer Academic Publishers, Dordrecht, 2002.

[34] M. Goedkoop, R. Spriensma, The Eco-indicator 99: a damage oriented method for life cycle impact assessment, Methodology report, 2001.

[35] M. Goedkoop, R. Spriensma, The Eco-indicator 99: a damage oriented method for Life Cycle Impact Assessment, Methodology Annex, 2001.

[36] G. Finnveden, et al., Recent developments in life cycle assessment, Journal of Environmental Management 91 (1) (2009) 1-21.

[37] T. Ekvall, B.P. Weidema, System boundaries and input data in consequential life cycle inventory analysis, The International Journal of Life Cycle Assessment 9 (3) (2004) 161-171.

[38] P.S. Vieira, A. Horvath, Assessing the end-of-life impacts of buildings, Environmental Science \& Technology 42 (13) (2008) 4663-4669.

[39] P. Lesage, T. Ekvall, L. Deschênes, R. Samson, Environmental assessment of brownfield rehabilitation using two different life cycle inventory models. Part 1. Methodological approach, International Journal of Life Cycle Assessment 12 (6) (2007) 391-398.

[40] P. Lesage, T. Ekvall, L. Deschênes, R. Samson, Environmental assessment of brownfield rehabilitation using two different life cycle inventory models. Part 2. Case study, International Journal of Life Cycle Assessment 12 (7) (2007) 497-513.

[41] H. Monteiro, F. Freire, Life cycle energy and environmental assessment of alternative exterior wall systems, in: L. Braganç, M. Pinheiro, R. Mateus, et al. (Eds.), Portugal SB10 Sustainable Building Affordable to All - Low Cost Sustainable Solutions Proceedings, Vilamoura, Portugal, 2010, pp. 777-784.

[42] H. Monteiro, F. Freire, Environmental life-cycle assessment of a single-family house in Portugal: assessing alternative exterior walls with two methods, Gazi University Journal of Science 24 (3) (2011) 527-534.

[43] H. Monteiro, Life cycle assessment of a Portuguese house with different exterior wall solutions and alternative heating systems, MSc thesis in Energy for Sustainability, University of Coimbra, 2010.

[44] D. Kellenberger, H.J. Althaus, N. Jungbluth, T. Künniger, M. Lehmann, P. Thalmann, Life cycle inventories of building products, Final report ecoinvent Data v2.0 No.7, Dübendorf, $\mathrm{CH}, 2007$.

[45] M. Spielmann, R. Dones, C. Bauer, M. Tuchschmid, Life cycle inventories of transport services, Ecoinvent report $\mathrm{N}^{\circ}$ 14, v2.0, Dübendorf, $\mathrm{CH}, 2007$.

[46] EN ISO 13790, Energy performance of buildings - calculation of energy use for space heating and cooling, ISO, 2008.

[47] ODYSSEE Energy Efficiency Database. http://www.odyssee-indicators.org registred/online-indicators/ (accessed September, 2011).

[48] H. Künzel, H.M. Künzel, K. Sedlbauer, Long-term performance of external thermal insulation systems (ETICS), Architectura Zeitschrift Für Geschichte Der Baukunst 5 (2006) 11-24. 